Original article / Оригинальная статья

УДК 664.11+577.1+547.9

DOI: https://doi.org/10.21285/2227-2925-2020-10-2-188-195

\title{
Formation of humic substances in the reaction of $D$-glucose with $p$-toluidine in anhydrous ethanol
}

\author{
(C) Igor S. Cherepanov, Polina S. Kryukova
}

Udmurt State University, Izhevsk, Russian Federation

\begin{abstract}
The aim of the study was to investigate the processes of formation and structural group composition of the products formed during the reaction of $D$-glucose with p-toluidine in anhydrous ethanol using electronic and vibrational spectroscopy methods. The evolution of the profiles of the electronic spectra of working solutions shows the formation of a chromophore system: clear peaks at 380 and $440 \mathrm{~nm}$ are already present at a reaction time of $60 \mathrm{~min}$. The appearance of an additional maximum at $520 \mathrm{~nm}(90,120 \mathrm{~min})$ likely corresponds to the formation of chromophores in condensed structures, as confirmed by a decrease in the values of the $E_{4} / E_{6}$ indices over time. The dynamics of the transformation of structural elements is also clearly seen in the analysis of IR spectra: as the reactions proceed, the $\mathrm{CH}$ aliphatic component of the structure decreases, while the aromatisation and functionalisation of products by chromophore groups increases. For products obtained between 90 and $120 \mathrm{~min}$, a clear band at $1656 \mathrm{~cm}^{-1}$, attributed to stretching vibrations of multiple bonds in conjugated $C=C-C=O$ systems and azomethine fragments, indicates the of condensation reactions. In the spectra of insoluble solid products fractionated by water, the intensity of the bands at 1656 and $1190 \mathrm{~cm}^{-1}$ is significantly reduced; this is possibly due to the transfer of some of the coloured low molecular weight products to the aqueous phase. A comparison of the IR Fourier transform spectra of the final solid products with the spectra of natural and synthetic humic-like substances indicates their similar structural group composition. The intensity of the bands at 1620, 1508 and $815 \mathrm{~cm}^{-1}$ indicates a significant contribution of the aromatic component to the structure of the products of water-insoluble fractions; the water-soluble fractions mainly include aliphatic oxygen-containing structures resulting from the oxidative destruction of the initial carbohydrate. The synthesised products seem promising as convenient plant growth regulators with controlled release of the active substance.
\end{abstract}

Keywords: D-glucose, p-toluidine, humic substances, ethanol media, spectroscopy

Information about the article: Received November 22, 2019; accepted for publication, May 29, 2020; available online June 30, 2020.

For citation: Cherepanov IS, Kryukova PS. Formation of humic substances in the reaction of D-glucose with p-toluidine in anhydrous ethanol. Izvestiya Vuzov. Prikladnaya Khimiya $i$ Biotekhnologiya = Proceedings of Universities. Applied Chemistry and Biotechnology. 2020;10(2):188-195. (In English) https://doi.org/10.21285/ 2227-2925-2020-10-2-188-195

\section{Образование гуминоподобных веществ в реакции $D$-глюкозы с п-толуидином в безводном этаноле}

\author{
И.С. Черепанов, П.С. Крюкова \\ Удмуртский государственный университет, г. Ижевск, Российская Федерация
}

Резюме: Целью исследования являлось изучение процессов образования и структурно-группового состава продуктов взаимодействия D-глюкозы с п-толуидином в среде безводного этанола методами электронной и колебательной спектроскопии. Эволюция профилей электронных спектров рабочих растворов показывает фрормирование хромофрорной системы: четкие пики при 380 и 440 нм регистрируются уже при продолжительности реакции 60 мин. Появление дополнительного максимума при 520 нм (90, 120 мин), вероятно, отвечает образованию хромофоров конденсированных структур, что подтверждается уменьшением значений индексов $E_{4} / E_{6}$ со временем. Динамика трансорормации структурных элементов также отчетливо прослеживается при анализе ИК-спектров: по мере протекания реакций СН-алифратическая составляющая структуры уменьшается, при этом увеличивается ароматизация и ффункционализация продуктов хромофрорными группами. Для продуктов, полученных в течение 90 и 120 мин термостатирования, в спектрах 
фиксируется четкая полоса при $1656 \mathrm{~cm}^{-1}$, относимая к валентным колебаниям кратных связей в сопряженных системах $\mathrm{C}=\mathrm{C}-\mathrm{C}=\mathrm{O}$ и азометиновых фррагментах, что указывает на протекание реакций конденсации. В спектрах фрракционированных водой нерастворимых твердых продуктов интенсивность полос при 1656 и $1190 \mathrm{~cm}^{-1}$ существенно снижается, возможно, за счет перехода части окрашенных низкомолекулярных продуктов в водную фразу. Сопоставление характера ИК-Фурье-спектров конечных твердых продуктов со спектрами природных и синтетических гуминоподобных веществ показывает их сходный структурно-групповой состав. Интенсивность полос при 1620, 1508 и $815 \mathrm{~cm}^{-1}$ свидетельствует о существенном вкладе ароматической составляющей в структуру продуктов водонерастворимых фрракций, при этом в состав водорастворимых фрракций входят в основном алифатические кислородсодержащие структуры, образующиеся в результате окислительной деструкции исходного углевода. Синтезированные продукты представляются перспективными в качестве доступных регуляторов роста растений с контролируемым выделением активного вещества.

Ключевые слова: D-глюкоза, п-толуидин, гуминовоподобные вещества, этанольные среды, спектроскопия

Информация о статье: Дата поступления 22 ноября 2019 е.; дата принятия к печати 29 мая 2020 2.; дата онлайн-размещения 30 июня. 2020 г.

Для цитирования: Черепанов И.С., Крюкова П.С. Образование гуминоподобных веществ в реакции $D$-глюкозы с п-толуидином в безводном этаноле. Известия вузов. Прикладная химия и биотехнология. 2020. Т. 10. N 2. С. 188-195. https://doi.org/10.21285/2227-2925-2020-10-2-188-195

\section{INTRODUCTION}

Synthetic analogues of natural compounds are important products of modern chemistry and chemical technology. One of the most accessible and widely studied are humic acids and humic substances, whose synthetic structural reproduction became possible in the middle of the 20th century [1, 2]. The interest in synthetic analogues of humic substances is driven by the need to obtain preparations that have valuable properties $[3,4]$. Thanks to the established and proven practically-significant properties of humic substances, various methods for their preparation, as well as the relationship between their structure and properties are currently being intensively studied. To date, both chemical [3, 4] and biochemical [5] methods for producing synthetic analogues of humins have been developed. Humic substances are known to display a wide range of known properties (antioxidant, antiviral, surface-active), and can be used as plant growth regulators [3,5]. These factors, as well as new works in the field of developed surface materials and nanostructures $[6,7]$ suggest the potential for further developments in the search for new reaction systems for synthesis. Particular attention in this case is given to systems based on simple carbohydrates $[3,6$, 7], presenting themselves as reactive and available substrates. Notably, synthetic humins based on monosaccharides were obtained under conditions of acid catalysis, the structure of which is represented by furan or furanic-aliphatic polymers $[3,4]$, distinguishing them from natural humic substances. The introduction of an active component of aromatic nature into the reaction system opens up additional possibilities for the synthesis of the target products [7], in which the solvent effect plays an important role. The solubility of carbohy- drates in ethanol-water solutions decreases significantly with an increase in the proportion of alcohol, which can shift the amino-carbonyl interactions in such systems into the partially heterogeneous category. In this case, process dynamics, which are determined by the desorption rate of products from the surface of the carbohydrate, for the most part do not depend on the nucleophilicity of the amine [8], expanding the possibilities of the classical Maillard reaction with the participation of aromatic amines [9]. In connection with the stated purpose of the present study, processes of formation and structural group composition of the products of the interaction of D-glucose with $p$-toluidine in anhydrous ethanol were examined.

\section{EXPERIMENTAL}

The synthesis of the target products was carried out in anhydrous (99.9\%) ethanol ("Merck") in the system $D$-glucose - $p$-toluidine of equimolar composition $(0.002 \mathrm{~mol})$ and heated in a threenecked flask with water heating and reflux at a thermostat temperature of $70{ }^{\circ} \mathrm{C}$ for a predetermined time. The absorption spectra of diluted samples selected during the processes $(0.1 \mathrm{ml}$ in $5 \mathrm{ml}$ of solvent) were recorded in quartz cuvettes $(I=1 \mathrm{~cm})$ on an SF-2000 spectrophotometer (OKB SPECTR, St. Petersburg, Russia) at a wavelength range of $300-700 \mathrm{~nm}$ with a step of $5 \mathrm{~nm}$. At the end of the measurement processes, the solvent was removed and the products, presenting themselves as black-brown substances, were washed with anhydrous ether and dried. Some of the products were fractionated with water. IR Fourier spectra of solid products were recorded in the transmission format in $\mathrm{KBr}$ pellets (1:250) on an FSM 2201 IR Fourier transform spectrometer (Infraspek LLC, St. Petersburg, 
Russia) in the wavelength range of $500-4000 \mathrm{~cm}^{-1}$ having a spectral resolution of $4 \mathrm{~cm}^{-1}$ with 40 scans. The initial spectra were processed in the FSpec and PeakFit software programs. The second derivative spectra were obtained as a result of numerical differentiation using smoothing by a fourth-order polynomial in windows up to 15 points. No fewer than three experiments were carried out.

\section{RESULTS AND DISCUSSION}

The direct determination of the structure of humic substances is greatly complicated by the compositional heterofunctionality and large number of combinations of structural units [10, 11]. In this case, IR spectroscopy, being a nondestructive method, provides fairly complete information about the set of basic atomic groups, as well as their mutual structural combination [12]. The dynamics of the transformation of structural elements can be clearly seen in the frequency analysis (Fig. 1):

- as the target processes proceed, a clear peak appears at $1190 \mathrm{~cm}^{-1}\left(\mathrm{v}_{\mathrm{C}-\mathrm{O}-\mathrm{C}}+\mathrm{v}_{\mathrm{C}-\mathrm{O}-\mathrm{N}}[13]\right)$, whose intensity increases with time;

- for products obtained at 90 and $120 \mathrm{~min}$ incubation, a fixed band at $1656 \mathrm{~cm}^{-1}$ is attributable to the stretching vibrations of multiple bonds in conjugated system $\mathrm{C}=\mathrm{C}-\mathrm{C}=\mathrm{O}$, indicating the condensation reaction [2].

Fractionation of final solid products with water allows the water-insoluble fractions to be isolated in the form of brown powders, in the spectra of which the main bands remain unchanged in time (Fig. 2, spectra 1,2), while the band intensities at 1656 and $1190 \mathrm{~cm}^{-1}$ decline. The latter may indicate the transition of some of the soluble coloured products to the aqueous phase, which, according to the authors of the publication [13], correlates with an increase in the band in the region of $1660 \mathrm{~cm}^{-1}$ and a decrease in the colour intensity of water-soluble fractions.

The nature of the vibrational spectra is a fairly reliable criterion for assigning the structure of products to a certain group of natural substances $[2,3,5]$. The assignment of the main bands in the IR Fourier transform spectra of solid products isolated from reaction systems shows the following structural group composition (see Fig. 2): $1720 \mathrm{~cm}^{-1}$ ( $\mathrm{v}_{\mathrm{C}=\mathrm{O}}$, shoulder), 1190, 1215, $1270 \mathrm{~cm}^{-1}$ $\left(\mathrm{v}_{\mathrm{CAr}-\mathrm{OH}}, \mathrm{v}_{\mathrm{C}-\mathrm{OH}}, \mathrm{v}_{\mathrm{C}-\mathrm{O}-\mathrm{C}}\right), 3400-3200 \mathrm{~cm}^{-1}\left(\mathrm{v}_{\mathrm{O}-\mathrm{H}, \mathrm{N}-\mathrm{H}}\right)$, aromatic system: 1508, 1580, $1622 \mathrm{~cm}^{-1}\left(\mathrm{~V}_{\mathrm{C}=\mathrm{C}}\right)$, $815 \mathrm{~cm}^{-1}(\mathrm{Y}=\mathrm{C}-\mathrm{H}), 3030 \mathrm{~cm}^{-1}\left(\mathrm{~V}_{=\mathrm{C}-\mathrm{H}}\right)$, as well as the limiting aliphatic constituent: $1000-1100 \mathrm{~cm}^{-1}\left(v_{\mathrm{CO}}\right.$ $\left.+\delta_{\mathrm{CO}}+v_{\mathrm{CC}}+\mathrm{v}_{\text {ring }}^{\mathrm{as}}\right), 2855,2922,2950 \mathrm{~cm}^{-1}\left(\mathrm{v}_{\mathrm{C}-\mathrm{H}}\right)$. The presence of intense bands at 1508 and $815 \mathrm{~cm}^{-1}$, as well as signals at $3030 \mathrm{~cm}^{-1}$ indicates the contribution of the uncondensed aromatic component characteristic of natural humic substances in the structure of products [10], which distinguishes them from previously synthesised carbonisation products [9]. Similar bands of corresponding intensity were observed by other authors in the IR spectra of natural and synthetic humic-like substances $[1-8,11,14]$, indicating their structural similarity with the products we isolated.

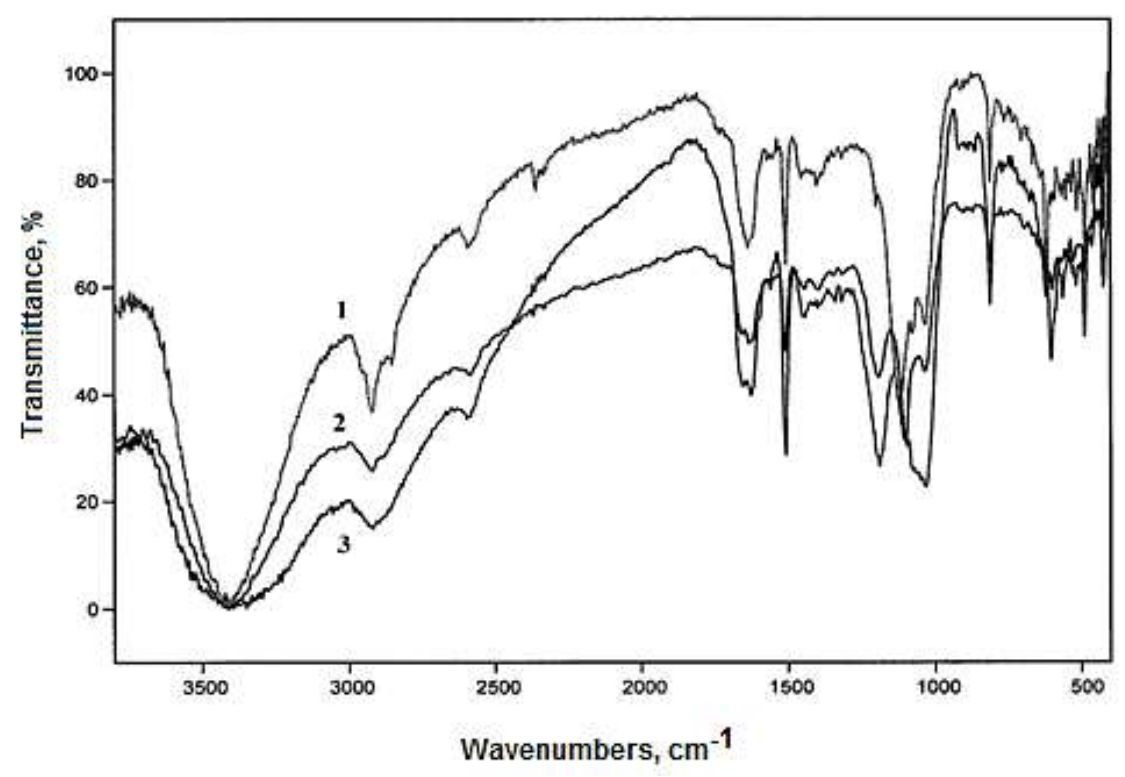

Fig. 1. IR-Fourier transform spectra of solid products isolated from reaction systems with different temperature control durations, min: 1-60; 2-90; 3-120

Puс. 1. ИК-Фурье спектры твердых продуктов, выделенных из реакционных систем при различной продолжительности термостатирования, мин: 1 - 60; 2-90; 3- 120 


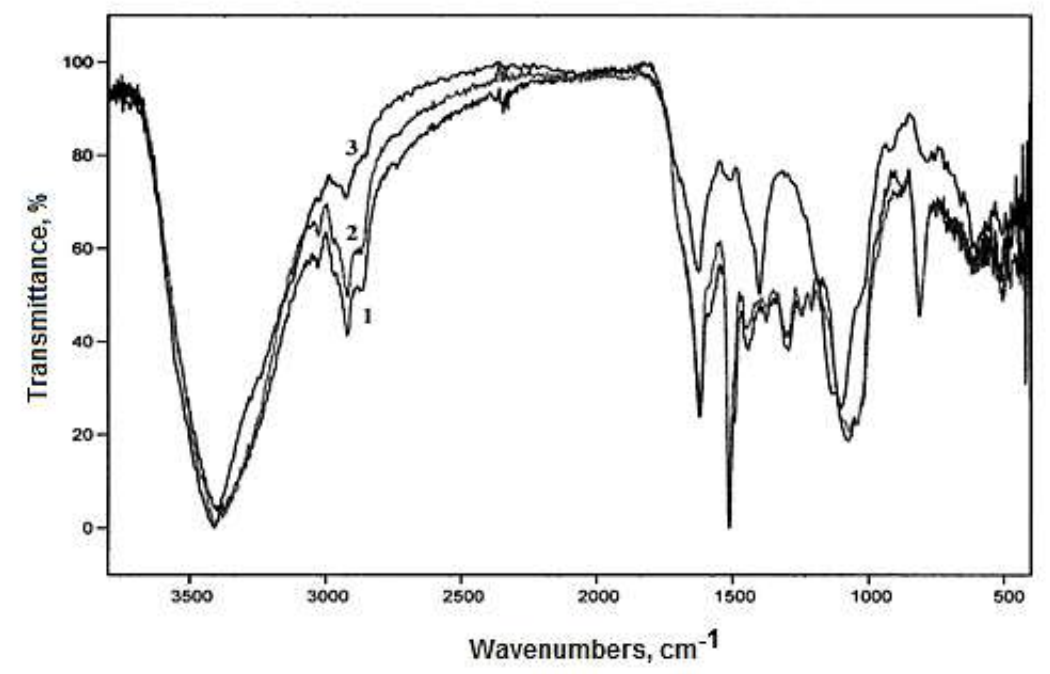

Fig. 2. IR-Fourier transform spectra of solid water-insoluble products isolated from reaction systems at different durations of temperature control, min:

1 - 60; 2 - 120; 3 - product of water-soluble fraction (120 min)

Рис. 2. Ик-Фурье спектры твердых водонерастворимых продуктов, выделенных из реакционных систем при различной продолжительности термостатирования, мин: 1 - 60; 2 - 120; 3 - продукт водорастворимой фракции (120 мин)

The electronic absorption spectra of the working solutions under the accepted experimental conditions are shown in Fig. 3. When analysing the nature of the profiles of their spectra, absorption in the entire wavelength range and increased optical density values are noted; this was not previously observed when using dried alcohol $(98 \%)$ as a solvent in the reaction of $D$-glucose with $p$-toluidine [9]. In addition, visual observations show the presence of an insoluble part of the carbohydrate that passes into the solution only at the end of the measurements.

The evolution of the profiles of the electronic spectra of working solutions shows the formation of a chromophore system: clear peaks at 380 and $440 \mathrm{~nm}$ are already present at a reaction time of $60 \mathrm{~min}$. The appearance of an additional maximum at $520 \mathrm{~nm}(90,120 \mathrm{~min})$ probably corresponds to the formation of chromophores of condensed structures. Similar spectra are charac-

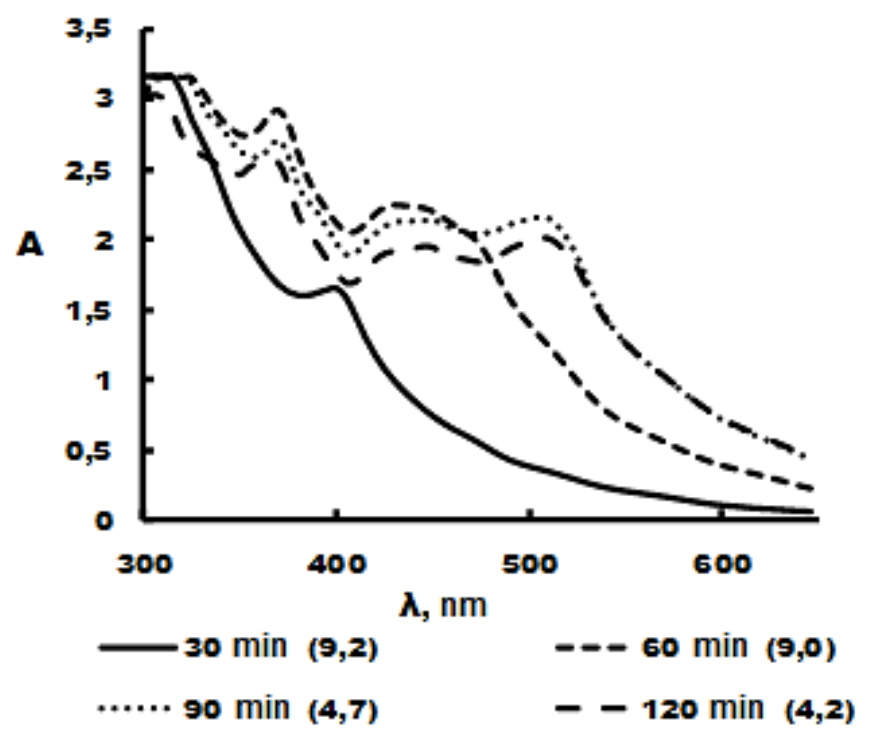

Fig. 3. Absorption spectra of process solutions and condensed products (values of $E_{4} / E_{6}$ indices are in brackets)

Рис. 3. Спектры поглощения рабочих растворов при различной продолжительности термостатирования (в скобках указаны значения индексов $E_{4} / E_{6}$ ) 


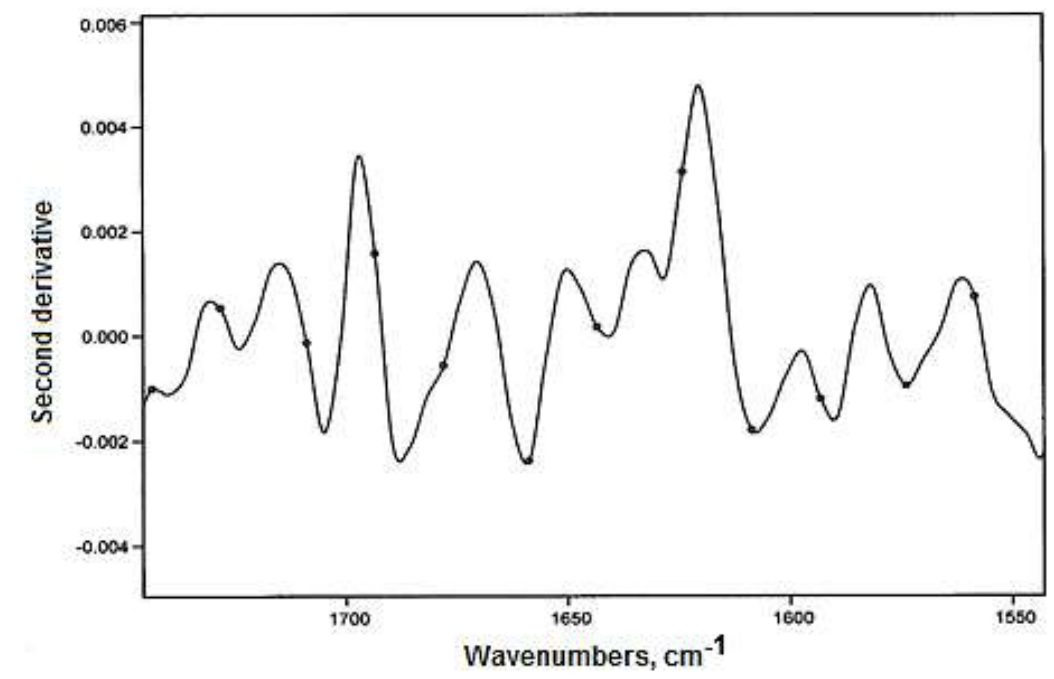

Fig. 4. IR-Fourier transform spectra second derivative of solid water-soluble product

Рuc. 4. Вторая производная ИК-Фурье спектра твердого продукта водорастворимой фракции

teristic of melectron systems of aromatic phenolic and quinoid structures [4], which is consistent with the vibrational spectroscopy data analysed above. A comparison of the indices $E_{4} / E_{6}$ calculated from the absorption values at $\lambda=465$ and $650 \mathrm{~nm}$ $[5,10]$ confirms this conclusion: the particularly sharp decrease in the index values from 60 to 90 min of temperature control indicates the formation of condensed conjugate and aromatic structures or intermolecular donor-acceptor complexes with charge transfer [10].

The decrease in the optical density of the solutions with a thermostating time of $120 \mathrm{~min}$ is probably caused by the precipitation of some products due to an increase in molecular weight and a decrease in solubility in the reaction medium. Thus, the chromophore system of the final products, which includes three absorption maxima (380, 440 and $520 \mathrm{~nm}$ ), begins to form by $60 \mathrm{~min}$ : this is represented by a combination of the aromatic component of the structure with oxygenand nitrogen-containing functional groups.

Removing the solvent from the water-soluble fraction allows a yellow solid residue to be isolated whose IR-Fourier transform spectrum differs from the spectra of the products of water-insoluble fractions (see Fig. 2, spectrum 3). In particular, the intensity of the "aromatic" bands of 815 and $1508 \mathrm{~cm}^{-1}$ is significantly reduced; the clear peak appearing at $1404 \mathrm{~cm}^{-1}$ probably corresponds to the vibrations of $\mathrm{C}(\mathrm{O}) \mathrm{OH}, \mathrm{OH}$, and $\mathrm{CH}[2,3,10]$. Signals at 1656 and $1190 \mathrm{~cm}^{-1}$ are not clearly recorded due to merging with wide bands with maxima at 1625 and $1137 \mathrm{~cm}^{-1}$. Twice-repeated differentiation of the IR-Fourier transform spectrum band in the interval $1800-1550 \mathrm{~cm}^{-1}$ allows the peak to be divided at $1625 \mathrm{~cm}^{-1}$ into several bands (Fig. 4), the most intense of which are at 1620 and $1705 \mathrm{~cm}^{1}\left(\mathrm{v}_{\mathrm{C}=\mathrm{C}}+\mathrm{v}_{\mathrm{C}=\mathrm{O}}\right)$. Less intense bands $\left(1584,1645,1670,1720 \mathrm{~cm}^{-1}\right)$ can also be attributed to functionalised oxygen fragments [15].

It can be assumed that the composition of water-soluble fractions consists mainly of aliphatic oxygen-containing structures formed as a result of oxidative degradation of the initial carbohydrate $[14,16,17]$; some of the bonds can be hydrolytically cleaved during fractionation [13].

The synthesised products have a number of important properties that are practically significant for their use as plant growth stimulants; in particular, the aromatic component. The authors of [12] showed that the growth-regulating activity of humic substances corresponds to an increase in their aromaticity. Other publications report the effectiveness of Schiff's aromatic bases on the yield of a number of agricultural crops [18, 19]. There has been growing interest in systems that are stable under natural conditions with controlled release of active substances [20]. For this reason, we are currently conducting studies to investigate the dynamics of fractionation of synthesised products, as well as vegetative experiments on test cultures in the Udmurt Republic.

Further studies are planned in the direction of studying the nature of the action of synthesised products on individual phases of plant development, as well as studies of their ecotoxicity and biodegradability. In the future, we also plan to develop a technological scheme that allows the process of synthesising growth regulators to be scaled up for industrial production.

\section{CONCLUSIONS}

Electronic and vibrational spectroscopy methods were used to study the formational and structural dynamics of products in the reaction of $D$-glucose with $p$-toluidine in anhydrous ethanol. The implementation of amino-carbonyl reactions 
of carbohydrates in non-aqueous alcoholic solutions can result in their significant intensification, allowing the procural of fractionated products structurally similar to substances of the humic class. The combination of the aromatic component of the structure with hydrolytically labile oxy- gen- and nitrogen-containing functional groups determines the biological activity during the growing season, which determines the prospect of using the synthesised products as available plant growth regulators with controlled release of the active substance.

\section{REFERENCES}

1. Goh KM, Stevenson FJ. Comparison of infrared spectra of synthetic and natural humic and fulvic acids. Soil Scince. 1971;112(6):392-400.

2. Stevenson FJ, Goh KM. Infrared spectra of humic acids and related substances. Geochimica et Cosmochimica Acta. 1971;35(5):471483. https://doi.org/10.1016/0016-7037(71)90044-5

3. Sumerskii IV, Krutov SM, Zarubin MYa. Humin-like substances formed under conditions of industrial hydrolysis of wood. Russian Journal of Applied Chemistry. 2010;83(2):320-327. https:// doi.org/10.1134/S1070427210020266

4. Litvin VA, Galagan RL, Minaev BF. Synthesis and properties of synthetic analogs of natural humic acids. Russian Journal of Applied Chemistry. 2012;85(2):296-302. https://doi.org/10.1134/S107 0427212020243

5. Koroleva OV, Kulikova NA, Alekseeva TN, Stepanova EV, Davidchik VN, Belyatva EYu, et al. A comparative characterization of fungal melanin and humic-like substances synthesized by Cerrena maxima 0275. Applied Biochemistry and Microbiology. 2007;43(1):61-67.

6. Liang L, Zhou M, Li K, Jiang L. Facile and fast polyaniline-directed synthesis of monolithic carbon cryogels from glucose. Microporous and Mesoporous Materials. 2018;265(1):26-34. https:

//doi.org/10.1016/J.micromeso.2013.01.035

7. Bai C, Shen F, Qi X-H. Preparation of porous carbon directly from hydrothermal carbonization of fructose and phloroglucinol for adsorption of tetracycline. Chinese Chemical Letters. 2017;28(5):960-962. https://doi.org/10.1016/j.cc let.2016.12.026

8. Shul'tsev AL. N-glycosides of 4-aminostyrene. Russian Journal of General Chemistry. 2014;84(2):235-241. https://doi.org/10.1134/S1070 363214020133

9. Cherepanov IS. Estimation of carbonized product's aromaticity in carbohydrate-arylamine systems. Izvestiya vysshikh uchebnykh zavedenii. Severo-Kavkazskii region. Tekhnicheskie nauki. 2018;4:118-123. (In Russian) https://doi.org/10.1 7213/0321-2653-2018-4-118-123

10. Gressel N, McGrath AE, McColl JG, Powers RF. Spectroscopy of aqueous extracts of forest litter. I. Suitability of methods. Soil Science Society of Arnerica Journal. 1995;59(6):1715-1723. https://doi.org/10.2136/sssaj1995.03615995005900 060030x

11. Van Zandvoort I, Koers E, Wiengarth $M$, Bruijnincx P, Baldus M, Weckhuysen B. Structural characterization of $13 \mathrm{C}$-enriched humins and alka- li-treated 13C-humins by 2D solid-state NMR. Green Chemistry. 2015;17(8):4383-4392. https: //doi.org/10.1039/C5GC00327J

12. Zherebtsov SI, Malyshenko NV, Votolin KS, Androkhanov VA, Sokolov DA, Dugarjav J. et al. Humic preparations: relation between structural group composition and biological activity. Vestnik Kuzbasskogo gosudarstvennogo tekhnicheskogo universiteta $=$ Bulletin of the Kuzbass state technical university. 2018;5:52-60. (In Russian) https://doi.org/10.26730/1999-4125-2018-552-60

13. Tsilomelekis G, Orella M, Lin Z, Cheng Z, Zheng W, Nikolakis $V$, et al. Molecular structure, morphology and growth mechanism and rates of 5-hydroxymethylfurfural (HMF) derived humins. Green Chemistry. 2016;18(7):1983-1993. https: //doi.org/10.1039/c5gc01938a

14. Yaylayan V, Kaminsky E. Isolation and structural analysis of Maillad polymers: caramel and melanoidin formation in glycine/glucose model system. Food Chemistry. 1998;63(1):25-31.

15. Yang Y-H, Sheng F-L, Tao Z-Y. Transmission FT-IR difference spectroscopic characterization of a fulvic acid from weathered coal in water. Toxicological and Environmental Chemistry. 1995;51(1-4):135-144. https://doi.org/10.1080/02 772249509358231

16. Jung $A-V$, Frochot $C$, Parant $S$, Lartiges BS, Selve C, Viriot M-L, et al. Synthesis of aminophenolic humic-like substances and comparison with natural aquatic humic acids: a multi-analytical techniques approach. Organic Geochemistry. 2005;36(9):1252-1271. https://doi.org/10.1016/j. orggeochem.2005.04.004

17. Patil SKR, Lund CRF. Formation and growth of humins via aldol addition and condensation during acid-catalyzed conversion of 5-hydroxymethylfurfural. Energy and Fuels. 2011;25(10): 4745-4755. https://doi.org/10.1021/ef2010157

18. Timofeev VP, Selimov FA, Dzhemelev UM. Aromatic Schiff's bases as growth regulator for plants. Patent RF, no. 210122; 1995. (In Russian)

19. Palande SV, Swamy DK. Synthesis, cha-racterization and biological activity of Schiff base 2\{[2-(2-metoxy-phenoxy)-ethylimino]-methyl\}phenol and its transition metal complexes. International Research Journal of Science and Engineering. 2018;A2:35-40.

20. Atabaeva MA, Dzhedzheya VT, Luss AL, Ustinova MS, Shtilman MI. Polymeric forms of plant growth regulators. Uspekhi $v$ khimii $i$ khimicheskoi tekhnologii. 2019;33(2):18-19. (In Russian) 


\begin{abstract}
БИБЛИОГРАФИ
1. Goh K.M., Stevenson F.J. Comparison of infrared spectra of synthetic and natural humic and fulvic acids // Soil Scince. 1971. Vol. 112. Issue 6. P. 392-400.

2. Stevenson F.J., Goh K.M. Infrared spectra of humic acids and related substances // Geochimica et Cosmochimica Acta. 1971. Vol. 35. Issue 5. P. 471-483. https://doi.org/10.1016/00167037(71)90044-5
\end{abstract}

3. Sumerskii I.V., Krutov S.M., Zarubin M.Ya. Human-like substances formed under conditions of industrial hydrolysis of wood // Russian Journal of Applied Chemistry. 2010. Vol. 83. Issue 2. P. 320327. https://doi.org/10.1134/S1070427210020266

4. Litvin V.A., Galagan R.L., Minaev B.F. Synthesis and properties of synthetic analogs of natural humic acids // Russian Journal of Applied Chemistry. 2012. Vol. 85. Issue 2. P. 296-302. https://doi. org/10.1134/S1070427212020243

5. Koroleva O.V., Kulikova N.A., Alekseeva T.N., Stepanova E.V., Davidchik V.N., Belyatva E.Yu., et al. A comparative characterization of fungal melanin and humic-like substances synthesized by Cerrena maxima 0275 // Applied Biochemistry and Microbiology. 2007. Vol. 43. Issue 1. P. 61-67.

6. Liang L., Zhou M., Li K., Jiang L. Facile and fast polyaniline-directed synthesis of monolithic carbon cryogels from glucose // Microporous and Mesoporous Materials. 2018. Vol. 265. Issue 1. P. 26-34. https://doi.org/10.1016/J.micromeso.20 13.01 .035

7. Bai C., Shen F., Qi X.-H. Preparation of porous carbon directly from hydrothermal carbonization of fructose and phloroglucinol for adsorption of tetracycline // Chinese Chemical Letters. 2017. Vol. 28. Issue 5. P. 960-962. https://doi.org/10.10 16/j.cclet.2016.12.026

8. Shul'tsev A.L. N-glycosides of 4-aminostyrene // Russian Journal of General Chemistry. 2014. Vol. 84. N 2. P. 235-241. https://doi.org/10. 1134/S1070363214020133

9. Черепанов И.С. Оценка параметров ароматичности продуктов карбонизации в системах углевод-ариламин // Известия высших учебных заведений. Северо-Кавказский регион. Технические науки. 2018. N 4 (200). C. 118-123. https://doi.org/10.17213/0321-2653-20 18-4-118-123

10. Gressel N., McGrath A.E., McColl J.G., Powers R.F. Spectroscopy of aqueous extracts of forest litter. I. Suitability of methods // Soil Science Society of Arnerica Journal. 1995. Vol. 59. Issue 6. P. 1715-1723. https://doi.org/10.2136/sssaj1995.03 615995005900060030x

11. Van Zandvoort I., Koers E., Wiengarth M., Bruijnincx P., Baldus M., Weckhuysen B. Structural characterization of $13 \mathrm{C}$-enriched humins and alkali-treated 13C-humins by 2D solid-state NMR //
Green Chemistry. 2015. Vol. 17. Issue 8. P. 43834392. https://doi.org/10.1039/C5GC00327J

12. Жеребцов С.И., Малышенко Н.В., Вотолин К.С., Андроханов В.А., Соколов Д.А., Дугаржав Ж. [и др.]. Гуминовые препараты: связь структурно-группового состава и биологической активности // Вестник Кузбасского государственного технического университета. 2018. N 5 (129). C. 52-60. https://doi.org/10.26730/1999-41 25-2018-5-52-60

13. Tsilomelekis G., Orella M., Lin Z., Cheng Z., Zheng W., Nikolakis V., et al. Molecular structure, morphology and growth mechanism and rates of 5-hydroxymethylfurfural (HMF) derived humins // Green Chemistry. 2016. Vol. 18.Issue 7. P. 19831993. https://doi.org/10.1039/c5gc01938a

14. Yaylayan V., Kaminsky E. Isolation and structural analysis of Maillad polymers: caramel and melanoidin formation in glycine/glucose model system // Food Chemistry. 1998. Vol. 63. Issue 1. P. 25-31.

15. Yang Y.-H., Sheng F.-L., Tao Z.-Y. Transmission FT-IR difference spectroscopic characterization of a fulvic acid from weathered coal in water // Toxicological and Environmental Chemistry. 1995. Vol. 51. Issue 1-4. P. 135-144. https://doi. org/10.1080/02772249509358231

16. Jung A.-V., Frochot C., Parant S., Lartiges B.S., Selve C., Viriot M.-L., et al. Synthesis of amino-phenolic humic-like substances and comparison with natural aquatic humic acids: a multi-analytical techniques approach // Organic Geochemistry. 2005. Vol. 36. Issue 9. P. 1252-1271. https://doi. org/10.1016/j.orggeochem.2005.04.004

17. Patil S.K.R., Lund C.R.F. Formation and growth of humins via aldol addition and condensation during acid-catalyzed conversion of 5-hydroxymethylfurfural // Energy and Fuels. 2011. Vol. 25. Issue 10. P. 4745-4755. https://doi.org/ 10.1021/ef2010157

18. Пат. № 2101227, Российская Федерация. Ароматические основания Шиффра в качестве регулятора роста растений / В.П. Тимофеев, Ф.А. Селимов, У.М. Джемилев; патентообладатель Стерлитамакский нефтехимический завод; заявл. 04.08.1995, опубл. 10.01.1998.

19. Palande S.V., Swamy D.K. Synthesis, characterization and biological activity of Schiff base 2\{[2-(2-metoxy-phenoxy)-ethylimino]-methyl\}phenol and its transition metal complexes // International Research Journal of Science and Engineering. 2018. Special Issue A2. P. 35-40.

20. Атабаева А.М., Джеджея В.Т., Лусс А.Л., Устинова М.С., Штильман М.И. Полимерные формы регуляторов роста растений // Успехи в химии и химической технологии. 2019. Т. 33. N 2. С. $18-19$. 


\section{Contribution}

Igor S. Cherepanov and Polina S. Kryukova carried out the experimental work, analyzed the experimental results and prepared the text of the manuscript. Igor S. Cherepanov and Polina S. Kryukova have equal author's rights and bear equal responsibility for plagiarism.

\section{Conflict of interests}

The authors declare no conflict of interests regarding the publication of this article.

The final manuscript has been read and approved by all the co-authors.

\section{INFORMATION ABOUT THE AUTHORS}

Igor S. Cherepanov, Cand. Sci. (Chemistry), Associate Professor, Udmurt State University, 1 Universitetskaya St., Izhevsk 426034, Russian Federation, e-mail: cherchem@mail.ru

\section{Polina S. Kryukova,}

Student,

Udmurt State University,

1 Universitetskaya St.,

Izhevsk 426034,

Russian Federation,

e-mail: cherchem@mail.ru

\section{Критерии авторства}

Черепанов И.С. и Крюкова П.С. выполнили экспериментальную работу, на основании полученных результатов провели обобщение и написали рукопись. Черепанов И.С. и Крюкова П.С. имеют на статью равные авторские права и несут равную ответственность за плагиат.

\section{Конфрликт интересов}

Авторы заявляют об отсутствии конфрликта интересов.

Все авторы прочитали и одобрили окончательный вариант рукописи.

\section{СВЕДЕНИЯ ОБ АВТОРАХ}

Черепанов Игорь Сергеевич, к.х.н., доцент Удмуртский государственный университет, 426034 , г. Ижевск, ул. Университетская,1, Российская Федерация, e-mail: cherchem@mail.ru

\author{
Крюкова Полина Сергеевна, \\ студентка, \\ Удмуртский государственный университет, \\ 426034 , г. Ижевск, ул. Университетская,1, \\ Российская Федерация, \\ e-mail: cherchem@mail.ru
}

